University of Nebraska - Lincoln

DigitalCommons@University of Nebraska - Lincoln

1929

\title{
Thomas Chrowder Chamberlin's Contribu-Tions To Glacial Geology
}

William C. Alden

United States Geological Survey

Follow this and additional works at: https://digitalcommons.unl.edu/usgsstaffpub

Part of the Earth Sciences Commons

Alden, William C., "Thomas Chrowder Chamberlin's Contribu-Tions To Glacial Geology" (1929). USGS Staff -- Published Research. 490.

https://digitalcommons.unl.edu/usgsstaffpub/490

This Article is brought to you for free and open access by the US Geological Survey at DigitalCommons@University of Nebraska - Lincoln. It has been accepted for inclusion in USGS Staff -- Published Research by an authorized administrator of DigitalCommons@University of Nebraska - Lincoln. 


\title{
THOMAS CHROWDER CHAMBERLIN'S CONTRIBU- TIONS TO GLACIAL GEOLOGY ${ }^{\mathrm{r}}$
}

\author{
WILLIAM C. ALDEN \\ United States Geological Survey \\ PREDECESSORS AND EARLY DAYS
}

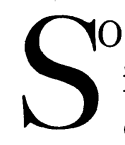

YO PROMINENT did Thomas Chrowder Chamberlin become in the field of glacial geology that it is a matter of some interest and importance to consider what was the status of the science at the time he turned his attention, as a student and a teacher, to it. So voluminous is the literature of this subject that it is obvious that one cannot in a sketch of this kind give even a general summary of the many books and papers on the subject published in this country, even were it desirable to do so. The intention is to indicate only what were some of the most notable investigations and publications. Some of Professor Chamberlin's most important contributions are undoubtedly woven into the warp and woof of the productions of the numerous men who were closely associated with him and carrying on field observations under his direction. So intimate were these relations that, as the writer himself found, it was sometimes difficult in the end to discriminate between the ideas which the student might feel were his own and those which he had absorbed from contact with the professor.

About fifty years before the birth of Thomas Chamberlin, which occurred in Mattoon, Illinois, in I843, references to scattered erratics, and what was later recognized to be glacial drift, began to appear in the scientific literature of North America. For a long time this material was regarded as diluvium, or the product of transportation by Noah's flood of biblical note, and many curious explanations were offered as to how this débris was transported and left scattered over hill and dale. The theory of transportation and deposition of

I Published by permission of the director of the United States Geological Survey.

The material for this sketch has been taken, very largely, from numerous publications supplemented by the writer's personal acquaintance. Dr. Rollin T. Chamberlin and several other geologists have aided by examining the first draft of the manuscript and giving suggestions. 
the drift of Northern Europe by a continental ice sheet, as postulated by Louis Agassiz in 1837 , was put on a firm foundation by the publication, in I840, of Agassiz' Etude sur les Glaciers, which set forth the results of his own studies, together with those of Charpentier, Venetz, and Hugi. In I846 Agassiz came to America and he very soon began the application of the theory of field studies of the drift in the United States. By the time Mr. Chamberlin had completed his undergraduate studies at Beloit College, in Beloit, Wisconsin, in I866, the caution with which the theory of continental glaciation was received, both in Europe and America, had given place to rather general, though not unanimous, acceptance among geologists. By this time also a great deal of material descriptive of the glacial formations in North America had been published by Edward and C. H. Hitchcock in New England; by Logan and J. W. Dawson in Canada; by the several geologists of the New York Geological Survey; by J. S. Newberry in the region of the Great Lakes; by Orton in Ohio; Alexander Winchell in Michigan; Worthen in Illinois; Owen and White in Iowa; N. H. Winchell in Minnesota, and by Owen, Lapham, Desor, Perceival, and Whittlesey in Wisconsin and the region of the Great Lakes.

\section{TEACHING AND THE WISCONSIN GEOLOGICAL SURVEY}

The school year 1868-69 was spent by Mr. Chamberlin in graduate study in several sciences at the University of Michigan, including work in geology with Alexander Winchell, who was then giving his best efforts to promote a higher grade of scientific instruction in the educational institutions of that state. The State Normal School at Whitewater, Wisconsin, where Chamberlin was professor of natural science in the years $1869-73$, is at the southern edge of the great Drumlin field of southeastern Wisconsin and in view of the abrupt inner, or ice-contact, face of the range of hills comprising the great Kettle moraine. This range of hills was one of his first and best-loved objects of field study. As the psalmist drew his strength from the hills, so Professor Chamberlin drew inspiration from the Kettle moraine and all that its full explanation implied. While the environment of Whitewater, Wisconsin, stimulated interest in glacial geology, the fact that the young professor occupied a 
whole settee rather than a chair in natural science at the State Normal School tended to broaden his foundation for later more specialized scientific studies.

From Whitewater, Chamberlin went to Beloit College, and there he spent the years $1873-82$ as professor of geology. The college at Beloit, Wisconsin, stands on the broad terrace top of the great deposit of outwash sand and gravel which fills the ancient valley of Rock River south of the terminal moraine of the Green Bay glacial lobe, and from the campus one looks across the postglacial channel of Rock River to the rolling drift-covered upland to the west, on which was the Chamberlin home farm. The professor was now in the thirties and his active participation in geologic investigations going on in Wisconsin is indicated by his being appointed assistant state geologist in 1873 . This position he held until 1876 , after which he served as state geologist of Wisconsin until I882. During this time he continued teaching geology at Beloit.

In 1854 Sir A. C. Ramsay, in England, and A. Marlot, in the Alps, had recognized that the Pleistocene embraced more than one epoch of glaciation, and Oswald Heer, in $185^{8}$, had brought to notice evidence of mild interglacial climate found in buried plant remains in the Alps. Such evidence was elaborated later by Professor James Geikie of the University of Edinburgh in the first, second, and third editions of the Great Ice Age, and by some other authors in Europe and by Edward Orton, N. H. Winchell, and a few others in the United States.

In the first edition of his Great Ice Age (issued in 1874) Geikie presented his ideas that there had been more than one glacial period and one or more interglacial periods, and that a glacial period had intervened since Paleolithic man left his stone implements in the deposits of Southern England. In the second edition he stated his conclusion that the later drift deposits were not the result of submergence and deposition from floating ice, but that there was an actual recurrence of advance of the ice sheets following a milder interglacial period.

The first of Professor Chamberlin's geologic papers was printed in 1875 by the Wisconsin Academy of Sciences, and the first of his publications treating of glacial drift, of which the writer finds men- 
tion, was in the Annual Report of the Wisconsin Geological Survey for the year 1876 when he was thirty-four years of age. This contribution consisted of three hundred and eight pages, including illustrations, tables, and text on the geology of eastern Wisconsin, and of this forty-eight pages treated of the Quaternary formations, the drift. The report was printed in Volume II, Geology of Wisconsin, the first of the four volumes to be published under his incumbency as state geologist. This volume was issued in the same year as the second edition of Geikie's Great Ice Age cited in the foregoing. In the descriptions of the glacial phenomena in Volume II, Geology of Wisconsin, Dr. Chamberlin did not definitely treat the glacial period as having comprised more than one advance and retreat of the ice. He states in one place that "the survey in the seventies swept over the Pleistocene formations and those that underlie them at the rate of about 4,000 square miles a year and thus perforce had something of the nature of a bird's-eye view." His studies of the Kettle moraine in eastern Wisconsin and its continuation in other states, however, led him to important conclusions and, in 1878 , he published in Transactions of the Wisconsin Academy of Sciences a paper entitled, "The Extent and Significance of the Wisconsin Kettle Moraine." In this he states:

The moraine constitutes a definite historical datum line in the midst of the glacial epoch and becomes a basis of reference and correlation for adjacent formations. It is an historical rampart outlining the great dynamic agency of the period at an important stage of its activity and separating the formations on either hand by a chronological barrier. ....

If the evidence adduced to show that the Kettle moraine was due to an advance of the glaciers be trustworthy, then to the extent of that advance, whether much or little, the moraine marks a secondary period of glaciation, with an interval of deglaciation between it and the epoch of extreme advance. Its great extent indicates that whatever agency caused the advance was very widespread if not continental in its influence. The moraine, therefore, may be worthy of study in its bearings upon the interesting question of glacial and interglacial periods.

In Volume I of the Geology of Wisconsin (the last of the set of four volumes prepared under his direction), which was submitted for publication in June, I882, and issued in I883, Chamberlin

I Preface to "The Quaternary Geology of Southeastern Wisconsin," by Wm. C. Alden, United States Geological Survey Professional Paper Io6 (I9I8), p. I3. 
inserted a discussion of the "second glacial epoch" and a note explaining why he had, in this volume, divided the glacial period in a way not done in the earlier volumes. He wrote ${ }^{\mathrm{I}}$

In the descriptive volumes of this report, two distinct glacial periods are not formally stated, although the fact of a second advance, with an intervening interval, is indicated. This was due partly to the fact that investigations were still in progress, which made it injudicious to prejudice results by broad conclusions in advance of the fullest available data, and partly to the fact that the existence of two such periods had not been generally recognized by American geologists, although the doctrine of separate glacial periods had been entertained by several in this country, following the lead of the Scotch school. The only American evidence then adduced, aside from theoretical presumptions, consisted of supposed superpositions of newer upon older till, separated by supposed interglacial deposits - a class of evidence to be received with great caution, since temporary oscillations, or the shifting of subglacial streams, may produce strikingly analogous phenomena. Where the section exposed to observation chances to be parallel to the glacial margin or the course of a subglacial stream, the phenomena may seem to be much more prevalent than is really the case. A further and more important ground of doubt arises from the fact that certain subaqueous deposits so closely resemble true till that they have been mistaken for it, and there is perhaps no case of superposition of beds supposed to represent two glacial periods that is not still open to these doubts. Our present firmness of conviction arises (I) from the discovery and working out of an extended moraine stretching across the whole of the glaciated area and belonging to a system of glacial movements which differ in many important respects from the earlier ones; and (2) from the differences of surface contour due to the greater erosion of the earlier, as already indicated. We believe that this line of evidence, when developed in its fulness, will prove entirely demonstrative. Only a small part of the results now gathered fall specifically within our present province as chronicler of the geological history of Wisconsin, but the total result is, in some important measure, the outgrowth of investigations begun in this State.

The subdivisions of the Quaternary age he presented as follows:

Quaternary age $\left\{\begin{array}{l}\text { Terrace or Fluviatile epoch } \\ \text { Champlain or Lacustrine epoch } \\ \text { Second glacial epoch } \\ \text { Glacial period } \\ \text { Interglacial epoch } \\ \text { First glacial epoch }\end{array}\right.$

The method of his treatment was used, as he wrote, "for the sake of ease and simplicity of description, rather than from a disposition

× Geology of Wisconsin, I (1883), 27 I-72. 
to ignore opposing opinion." His discussion may be summarized as follows:

The ice of the first glacial epoch was portrayed as entirely surrounding but not overrunning the great Driftless Area. The extent of the ice of his second glacial epoch, as shown for the Upper Mississippi Valley, approximates the areas at present known to be covered by drift of middle and late Wisconsin age. The movements of the ice were shown to have taken place "without regard to the local slope of the surface." The final retreat of the ice was attended by oscillations of the glacial front as represented by the formation of later secondary moraines. The drift-buried vegetal deposits, the so-called "forest beds" of Wisconsin, were stated to "belong to at least three epochs, one of which is the interglacial one here noted."

Following Agassiz, Forbes, and Tyndall, the flowage of glacier ice was said to be "essentially similar to that of viscous fluids." He found a striking accordance between the glacial phenomena of Wisconsin and Croll's hypothesis as to the cause of the glacial climate. He expressed grave doubt as to the competency of both preglacial and glacial erosion combined to have produced the basins of the Great Lakes, believing that one element was "a subsidence of their bottoms due to glacial occupancy."

\section{GLACIAL GEOLOGY AND THE FEDERAL SURVEY}

In 1879 the United States Geological Survey was established and in $\mathrm{I} 88 \mathrm{I}-82$ Dr. Chamberlin, then about thirty-eight years of age, began under its auspices studies of the drift in the various states. He continued as geologist in charge of the glacial division until 1904, and summaries of the glacial investigations under his direction appear in the successive annual reports of the director of the Geological Survey. During the years $1882-87$ he resided in Washington, D.C., except when absent on field studies, and in $1885^{-}$ 87 he served as professor of geology at Columbian (now George Washington) University in the capital city.

Professor Chamberlin now continued his studies of the extent and relations of the Kettle moraine and the several associated moraines, which he had already begun in states other than Wisconsin. In this work he associated others with him: Professor J. E. Todd in the area between the Mississippi and the Missouri rivers, and Professor L. C. Wooster in Michigan; he himself also worked in Ohio and New York in an attempt to make connections with the eastern extension of the moraine which had previously been traced 
across New Jersey and along the southern coast of New England by Cook, Smock, Upham, and King and, on Long Island as early as I842, by Mather. The results of these and previous studies in the several states from Dakota Territory to the Atlantic Coast were brought together in a notable "Preliminary Paper on the Terminal Moraine of the Second Glacial Epoch," published in 1883 in the Third Annual Report of the United States Geological Survey. In this article tentative correlation was made eastward through the upper Susquehanna basin and the Finger Lakes region of New York, and thence to the Catskills and south, i.e., far back of the "extreme terminal moraine" which H. C. Lewis and G. F. Wright had mapped along a line trending southeastward across northeastern Pennsylvania from Olean, New York, to the Delaware near Belvidere, New Jersey, and which Chamberlin was then inclined to regard as having been formed at an earlier epoch of glaciation. He, however, definitely indicated that these correlations and interpretations were tentative and might require later revision. The character of the mapping between Montana and the Atlantic Coast, sketched by the author of this paper in the Third Annual Report, may readily be seen by comparison of these maps with the later ones. Much more complexity of detail has since been worked out, yet the importance of this paper was very great at the time of its publication. Professor Chamberlin had shown that his "terminal moraine of the second glacial epoch" lay far within the outer limit of the drift throughout much of its course across the Mississippi basin. The idea of duality of the glacial period was not, however, accepted by all geologists.

During the later I880's Dr. Chamberlin visited many parts of the glaciated field and he also examined the loess and "orange sand" of the Lower Mississippi Valley, finding in the latter no evidence of glaciofluvial origin. He continued his studies in the Dakotas with Todd and King and extended his own reconnaissance as far as the Puget Sound region. He also enlisted many others in glacial studies under the auspices of the federal survey: R. D. Salisbury examined the Driftless Area of the Upper Mississippi Valley and the outer border of the drift in Missouri; G. F. Wright mapped the limit of the drift between the Mississippi River and western Pennsylvania, and studied the terraces of the Allegheny; G. H. Stone studied the 
osars of Maine, and William Davis the drumlins of Massachusetts, Connecticut, and New York; I. M. Buell traced the boulder trains of Wisconsin; J. E. Todd mapped the glacial deposits in the Dakotas, Iowa, and Nebraska; Warren Upham carried on a comprehensive study of glacial Lake Agassiz; N. S. Shaler studied Mt. Desert Island, Maine, Nantucket, and Marthas Vineyard; J. C. Branner worked in Ohio and eastern Indiana. In I886 Mr. Frank Leverett began in northeastern Illinois, under the supervision of Professor Chamberlin, the notable studies of the glacial deposits for the United States Geological Survey, which he has continued almost without break to the present day.

From these various studies came numerous papers and important monographs by these scientists, and also short papers and discussions by the geologist in charge.

In $\mathrm{I} 888$, after Dr. Chamberlin had become president of the University of Wisconsin, there was published in the Seventh Annual Report of the United States Geological Survey his paper on "The Rock Scorings of the Great Ice-Invasions" in which he illustrated, and drew inferences concerning, the modes of glacial action from a remarkable variety of such glacial scorings. A map issued with this paper shows the extent of the earlier and later glaciations throughout the United States as then known. In the later r880's and early I89o's Chamberlin himself did little more in glacial geology on the federal survey than direct the studies being carried on by Upham, Todd, Stone, Buell, Wooster, Salisbury, and Leverett. Most of these men were working on their reports when not engaged in teaching or otherwise, and only Upham and Leverett gave their full time to United States Geological Survey work.

Dr. Chamberlin took an active part in the discussion of all phases of the glacial problems at the meetings of the Geological Society of America for many years after the foundation of the society in I889. He was particularly vigorous in his opposition to the idea that there was but one period, or epoch, of glaciation and to the interpretation of the attenuated drift outside the moraine in Pennsylvania as a so-called "fringe" or dependency of the moraine. This outer drift he regarded as the product of a glacial epoch distinctly older than that which formed the moraine. As stated in the Bulletin of the 
Geological Society of America, Volume I, he found evidence concerning the interval between the glacial epochs in the following:

a) Considering the loess of the Mississippi Valley as waterlaid, he concluded it originally extended clear across from side to side and that the inner valley, three hundred feet deep and sixty miles wide, from Cairo, Illinois, to the Gulf, had been eroded in interglacial time, before it received the filling of silts washed out from the ice of the later epoch.

b) The cutting of the inner gorge of the Allegheny River, about two hundred fifty feet deep, below the level of rock terraces which carry outwash gravel he correlated with the older drift.

c) Similar evidence was also found on the Susquehanna and Delaware rivers.

In 1890 Chamberlin's interpretation of the terraces of the Allegheny River was published in an introduction to United States Geological Survey Bulletin 58, entitled "The Glacial Boundary in Western Pennsylvania, Ohio, Kentucky, Indiana, and Illinois," by G. F. Wright, in which the latter sets forth quite different ideas. One of the hypotheses set forth in this bulletin which Professor Chamberlin strongly opposed was that the deposits on the upper terraces were due to an ice dam five hundred fifty feet high, formed when the glaciers crossed the Ohio into Kentucky in the vicinity of Cincinnati. Such a dam, Wright concluded, had ponded waters to heights of three hundred feet or more above the river level in the Upper Ohio Valley and caused the tributaries to make the high terrace deposits, some of them on rock-cut terraces, which he considered too old to be of Pleistocene age. Chamberlin thought temporary and partial blocking by such an ice dam "was an extremely probable and frequent occurrence but not a permanent damming."

In I891 Chamberlin and Salisbury presented their interpretations in an article entitled "On the Relationships of the Pleistocene to the Pre-Pleistocene Formations of the Mississippi Basin South of the Limit of Glaciation." The following is a brief summary of important points set forth in this paper:

No soil or weathered zone was found at the top of the drift and below the loess in southeastern Illinois and southwestern Indiana. The loess is an aqueous

I American Journal of Science, XLI, series 3 (I89I), 359-77. 
deposit formed immediately after the till at the closing stage of the first glacial epoch. This epoch had two episodes with "forest bed" formed between them. The loess is unconformable on the "Orange sand." The latter is deeply weathered from long pre-loess exposure. There are no drift pebbles in "Orange sand." The "Orange sand" is pre-Pleistocene. Some indications were seen at a few places of a fluvial "loess" of the first episode of the first glacial epoch. There are two loesses in Illinois, Kentucky, Tennessee, Arkansas, and Missouri. There was depression and slack water to cause the loess deposition, and re-elevation and erosion. Later glacial terraces slope down to and disappear under the filling of the Lower Mississippi.

In a paper on the cause of glaciation, ${ }^{\mathrm{x}}$ presented before the Geological Society of America, Professor Chamberlin rejected Croll's astronomical hypothesis and also high elevations as causes. He suggested that there might have been such a change in the axis of rotation of the earth as to bring the glaciated areas into high latitudes. In a "proposed genetic classification of Pleistocene glacial formations," presented before the International Geological Congress, he grouped loess with "formations produced by glacial waters after their issuance from Pleistocene glaciers" and eolian loess with "formations produced by winds on Pleistocene glacial and glaciofluvial deposits under the peculiar conditions of glaciation."

In 1892 , at about forty-nine years of age, Dr. Chamberlin became head of the department of geology at the newly organized University of Chicago and, gathering about him there a select faculty and a rapidly growing body of students, he found conditions congenial for the study and teaching of the fundamentals of geology and particularly of glacial geology. Here the Journal of Geology was founded in 1893 , with himself and his colleagues as editors. This journal formed a convenient medium of publication and among its special articles and editorials are many of his own treating of various problems of glacial geology. A scanning of its pages affords a ready means of access to his most notable studies for the next thirty-five years.

\section{MAN AND THE GLACIAL PERIOD}

Professor Chamberlin was much interested in the subject of the time of man's appearance in America, but he did not regard as valid the evidence brought forward by several scientists that primitive

I T. C. Chamberlin, "The Present Standing of the Several Hypotheses of the Cause of the Glacial Period," American Geologist, VIII (I89r), 237 (abstract). 
Paleolithic man reached North America prior to the last glaciation. Together with R. D. Salisbury and W. H. Holmes, he regarded the so-called "paleoliths" found in North America as merely the rejects from the manufacture of better stone implements. He published articles by Professor Holmes in the Journal and had him instruct students in geology at the university in the critical scrutiny of the conditions under which artifacts became imbedded in glacial and glaciofluvial deposits, and how to interpret them. Such scrutiny led him later to reject the interpretations placed by some on the buried human remains found near Lansing, Kansas (1902), and Florence, Nebraska. In his discussion of the geologic relations of the human relics of Lansing, Kansas, ${ }^{x}$ he gave what Dr. Samuel Calvin ${ }^{2}$ characterized as a

full and clear presentation of the behavior of rivers of the Missouri type in connection with migrations of their meanders, of their work in degradation and aggradation, in scour-and-fill, while deepening and widening their valleys, and of the changing conditions which they impose on their tributaries.

By 1893 Professor G. F. Wright, on the basis of his own interpretations, had come to agree with Chamberlin and Salisbury, that the ice had extended far beyond the terminal moraine in New Jersey, but he did not regard the outer drift as of an older glacial epoch. The Chicago men vigorously opposed Wright's interpretation that the material was already weathered when it became incorporated in the drift. Professor Chamberlin (I894), in a review of J. W. Dawson's Canadian Ice Age, dissented radically from that author's fundamental conclusions. Dawson's conception of the Pleistocene included:

a) Earlier Pleistocene-Laurentian and Greenland ice sheets and local glaciers.

b) Middle Pleistocene-a mild interglacial epoch.

c) Later Pleistocene-glaciers in mountains, with the interior plains submerged and the later drift being dropped from icebergs.

\section{CLASSIFICATION OF THE QUATERNARY DEPOSITS OF NORTH AMERICA}

In 1894 the third edition of James Geikie's Great Ice Age was published in Europe with a map and two chapters by T. C. Cham-

\footnotetext{
I Journal of Geology, X (I902), 745-77. $\quad 2$ Op. cit., p. 777 .
} 
berlin on the glacial phenomena of North America, and in this very important description names were suggested, for the first time, for the different stages, as the writer there designated them. He gave two different possible groupings on a twofold basis, together with the following grouping on a threefold basis, which he regarded as, in many respects, the most satisfactory interpretation from the glacial deposits themselves:

\section{GLACIAL PERIOD}

I. Concealed under series (theoretical)...... Unknown.

2. Kansan stage of glaciation............. First (represented) glacial epoch.

3. First interval of deglaciation........... First interglacial epoch.

4. East-Iowan stage of glaciation.......... Second glacial epoch.

5. Second interval of deglaciation.......... Second interglacial epoch.

6. East-Wisconsin stage of glaciation....... Third glacial epoch.

7. Later oscillations of undetermined (Third glacial epoch embracing importance.................. possibly a fourth glacial epoch.

Neither Geikie nor Chamberlin supported, in this volume, any one definite theory as to the cause of glaciation. The attitude of both may be indicated by one of Geikie's closing sentences as follows: "The primary cause of those remarkable changes is thus an extremely perplexing question and it must be confessed that a complete solution of the problem has not yet been found."

In an article in the Journal of Geology, ${ }^{,}$James Geikie discussed the "classification of the European glacial deposits," and suggested names for six glacial epochs and five interglacial epochs, and Dr. Chamberlin printed an article in the same number of the Journal on the "classification of the American glacial deposits," suggesting parallelism, rather than correlation with the European deposits, and giving the names as follows:

I. Kansan formation (=Saxonian?).

2. Aftonian formation (= Helvetian?).

3. Iowan formation (= Polandian?).

4. Toronto formation (=Neudeckian?).

5. Wisconsin formation (= Mecklenburgian?).

Chamberlin did not maintain that the three glaciations were of equal importance or that the two deglaciations were equal. He had,

I Vol. III (1895). 
in I894, presented in the Journal a "genetic classification of the Pleistocene glacial formations."

In 1892 the present Geological Survey of Iowa was organized, with Dr. Samuel Calvin as state geologist, and began study and mapping of the state by counties. This involved detailed study of the glacial deposits, including those in northeastern Iowa which had previously been studied by W. J. McGee. Dr. Chamberlin was greatly interested in these studies, as also in those of McGee, and he was rather closely associated therewith in consultation and field conferences. By 1895 these studies had resulted in an important change in the classification of the drift deposits of Iowa. Concerning this Chamberlin wrote in an editorial in the Journal of Geology in part as follows:

The studies of the past two years seem to show that within the limits of the series covered by the three names first proposed, there is, probably, need for some extension and revision. This arises chiefly from the progress made by the geologists of the Iowa survey, Messrs. Calvin, Bain, Norton and Beyer, and by my colleague, Mr. Leverett. It will be recalled that in eastern Iowa the elaborate investigations of Mr. McGee, some years ago, demonstrated the existence of two sheets of till, separated by a vegetal horizon. It was known that in southern Iowa there were also two sheets of till separated by a vegetal horizon, but these had not been studied in detail nor their connections traced out. It was natural, as well as prudentially conservative, to suppose that these two series were mutual equivalents, as they stood in much the same geographic relationship to the later (Wisconsin) drift. It was recognized that the amount of erosion upon the south Iowan series was greater than that upon the east Iowan, and also that the loess in eastern Iowa was intimately connected with the upper till sheet, while the upper till sheet in southern Iowa was separated from the loess by a definite interval, but the importance of these differences was not fully appreciated. The investigations of the Iowa geologists have led to the quite firm conviction that the upper till sheet of the series in southern Iowa is the lower member in eastern Iowa. They have also become convinced that the upper sheet in southern Iowa extends continuously across northwestern Missouri into Kansas, and is the equivalent of the drift sheet that covers the northeastern part of Kansas. State Geologist Keyes of Missouri concurs in this view. They do not hold this to the exclusion of a possible lower member in Kansas. In harmony with these views the upper till in the southern part of Iowa has been designated Kansan in the recent Iowa reports.

During the past summer I have had the pleasure of making two excursions with Mr. Bain of the Iowa survey to localities where the above formations are advantageously exhibited, and I have been impressed with the cogency of the 
arguments of the Iowa geologists. While, therefore, the case cannot be said to be demonstrative, as yet, it seems best to accept the application of the nomenclature adopted by the Iowa survey. This places the Aftonian beds below the Kansan series instead of above them. It puts the sub-Aftonian sheet of till in an earlier category, and, for the present, it may perhaps be regarded tentatively as Albertan, although, of course, it cannot now be demonstrated to be equivalent to the Albertan beds of Canada. The studies of $\mathrm{Mr}$. Leverett have made it quite sure that the Kansan ice-sheet crossed the Mississippi and invaded Illinois to some moderate distance. He has also shown that the Illinois icesheet returned the compliment and invaded Iowa. Between these invasions there was a considerable interval of time, as indicated by the greater erosion of the Kansan deposits and by the prevalence of a soil horizon and of peat beds between the Kansan and Illinois till sheets where they overlap. He has shown also that there was a notable interval between the invasion of Iowa by the Illinois ice-sheet and the spreading of the loess over its deposits, as indicated by erosion and the formation of a soil horizon. This loess mantle seems to be identical with that which is intimately connected with the east Iowan drift sheet. It thus appears that the invasion of the Illinois ice marks a distinguishable stage of glaciation separated by a notable interval from both the earlier Kansan stage and the later Iowan stage. This interval appears to be of such moment as to make it inadvisable to correlate the Illinois drift sheet with the Iowan drift sheet. As a result, the practice of designating the former the Illinois sheet has already sprung up among us. The evidence at present seems sufficient to justify its tentative use in the literature of the subject. It should of course be credited to Mr. Leverett.

The series of the Mississippi basin, as thus modified, would be as follows in stratigraphic order:

9. Wisconsin Till Sheets (earlier and later).

8. Interglacial deposits (Toronto perhaps).

7. Iowan Till Sheet.

6. Interglacial deposit.

5. Illinois Till Sheet (Leverett).

4. Interglacial deposit (Buchanan of Calvin).

3. Kansan Till Sheet.

2. Aftonian beds, Interglacial.

I. Albertan Drift Sheet (Dawson). ${ }^{\mathrm{x}}$

In the same editorial there was printed the following memorandum, which has been used many times since:

.... While returning from my last visit to the field in which the Kansan, Illinoian, Iowan, and Wisconsin formations were seen in close succession, I made a memorandum of impressions respecting their relative ages simply as a means of comparison with judgments formed at other times, the impressions

I Journal of Geology, IV (I896), 872-74. 
being derived from the respective degrees of erosion and chemical change which the formations have undergone. Although this was intended to be nothing more than a record of passing impressions, it may be the best means of giving some notion of my rating of the historical importance of the formations. Taking the interval from the late Wisconsin deposits (as found immediately south of the Great Lakes) to the present date as unity, the following is the memorandum: From the close of the later Wisconsin to the present.......... I unit From the earliest Wisconsin (Shelbyville moraine) to the present... $2 \frac{1}{2}$ units From the Iowan to the present..................... 5 units From the Illinois invasion of Iowa to the present............ 8 units From the Kansan to the present..................... I5 units From the sub-Aftonian (Albertan) to the present........... $\mathrm{x}$ units

Four of the investigators previously named who have seen this memorandum are disposed to increase the figure for the Kansan, and some of them would alter other figures in the same direction, with perhaps a reduction of the estimate for the Iowan. After the estimate had been made it was observed that the intervals form a symmetrical diminishing series. The temperature variations of the period might therefore be represented by an oscillating curve with declining waves.

Perhaps in no way was Professor Chamberlin's profound interest in (one might almost say affection for) the glacial formations of his homeland, the Upper Mississippi Valley, more manifest than in the matter of the classification and nomenclature of the drift sheets which he had done so much to establish. This was particularly impressed upon the writer on the occasion of a last visit early in June, I928, when the old doctor sat back in his evening chair and, with considerable feeling, recounted the circumstances attending the development of the Pleistocene classification of Iowa. He never became reconciled to the shifting of the name "Kansan" from the subAftonian till to the super-Aftonian till nor the limiting of the name "Iowan" to the thin uppermost till, in northeastern Iowa, McGee's original area. Even to his dying day, and long after the altered nomenclature had become well established in geologic literature, he cherished the hope that the name "Iowan" would be restored, as he thought it should be, to the great drift sheet which is the upper till throughout the southern half of Iowa, and which extends thence into Missouri, Kansas, and Nebraska. It seemed to him that, when a relatively thin sheet of drift was differentiated in northeastern Iowa as later than the great statewide sheet of super-Aftonian till, 
it should have been given another name. It was to him as though the state had in some very real sense been bereft of an important feature of its birthright. In the Journal of Geology, ${ }^{\mathrm{I}}$ in a review of an article by Mr. Leverett, Dr. Chamberlin gave an expression of his opinion of the classification, in part, as follows:

The name Kansan has been shifted from the sub-Aftonian till to the superAftonian till originally called Iowan. The term Iowan thus displaced has been transferred from the middle drift to the uppermost and least member of the grouped beds originally covered by them. The reason for these shifts seemed cogent to the workers in the Iowan field at the time they were made and perhaps seem so still. They were accepted with slight reluctance by the glacialist who had given the terms their original applications. The cogency of the reasons for the changes has, however, from his point of view, largely disappeared with the progress of study, and if it were practicable to return essentially to the original usage, making the sub-Aftonian till Kansan and the super-Aftonian till Iowan, and to take the exceptional exposures of both formations near Afton Junction, Iowa, as the types, as was originally done, it would seem to him to accord best with the inherent fitness of the case. Particularly does this seem so in the application of the term Iowan, for the super-Aftonian till not only has a broader and more distinctive expression in Iowa than anywhere else, but it is the greatest of Iowa's drifts; it is inherently the Iowan drift. . . . .

This sketch, even in its incompleteness, may serve to give a measure of historic insight into the embarrassments that attend the correlation and nomenclature of the American middle drift.

Respecting the newer divergencies of opinion implied in Mr. Leverett's paper, which involve the suggested dismissal of the Iowan altogether, as a distinct formation, or else its grouping under the Illinoian, it is appropriate here to urge restraint, patience, and equipoise, for the distinguishing phenomena, while pronounced and peculiar, are subtle in their gradations and singularly puzzling.

In I894 Mr. Leverett, working under Chamberlin's supervision, had differentiated a drift sheet in southeastern Iowa, which appeared to be younger than the drift exposed farther west. From its lithologic composition he concluded that this drift was deposited by ice which came from the center of glaciation on Labrador peninsula and which crossed the channel of the Mississippi River and invaded Iowa from the east. This was found to be the uppermost till sheet throughout most of that part of Illinois outside the limits of the Wisconsin drift, so the name "Illinoian drift" was chosen as an appropriate designation.

\footnotetext{
${ }^{\prime}$ XVIII (I9I0), 473.
} 
In $1898 \mathrm{Mr}$. Leverett ${ }^{\mathrm{I}}$ had proposed the names Yarmouth, Sangamon, and Peorian for three of the interglacial stages, so that (omitting the later substages) the Pleistocene classification as presented by Mr. Leverett in Monograph 38, The Illinois Glacial Lobe (I899), was as follows:

\section{OUTLINE OF THE DRIFT SHEETS AND INTERVALS}

Stage 1.-Oldest recognized drift sheet-the Albertan of Dawson, including, also, the sub-Aftonian of Chamberlin.

Stage 2.-First interval of deglaciation-Aftonian of Chamberlin.

Stage 3.-Kansan drift sheet of the Iowa geologists.

Stage 4.-Second interval of recession or deglaciation-Yarmouth of Leverett.

Stage 5.-Illinoian drift sheet.

Stage 6.-Third interval of recession or deglaciation-Sangamon of Leverett.

Stage 7.-- Iowan drift sheet and main loess deposit.

Stage 8.-Fourth interval of recession or deglaciation-Peorian of Leverett, possibly equivalent to the Toronto Formation of Chamberlin.

Stage 9.-Early Wisconsin drift sheets.

Monograph 38 was the third of several monographs on Pleistocene phenomena to be completed under Dr. Chamberlin's supervision. The first of these works was Monograph 25, The Glacial Lake Agassiz, by Warren Upham, issued in I896, and the second was Monograph 34, The Glacial Gravels of Maine and Their Associated Deposits, by G. H. Stone, issued in I899. All of these monographs of the United States Geological Survey were notable publications presenting, as they did, the results of years of field mapping and study. In a review of Monograph 38 , Dr. Chamberlin wrote in part:

In the matter of classification, the monograph presents the latest and fullest expression of the conclusions toward which investigations in the interior have been steadily tending for the past decade. The classification offered is not regarded as final, either in the sense of including all the possible great divisions, or in the complete characterization of those recognized, but it clearly lies in the line of a true and ultimate classification. Fifteen stages are recognized, six of which are based upon notable glacial advances, five represent notable intervals of deglaciation, and four are based upon lacustrine stages after the beginning of the abandonment of the region by the last ice-sheet. The age of the oldest glacial formation is regarded as many times that of the latest; and the oldest

IJournal of Geology, Vol. VI. 
interglacial intervals are also believed to be many times longer than the later ones. In a word, the oscillations appear to have been large in the earlier stages and to have grown less and less during the progress of the period. This newer view of the relative ages of the successive epochs, sustained as it appears to be by the progress of research in Europe, must be looked upon as one of the most important advances of recent years, for it affects profoundly nearly all of the larger questions of glacial history. ${ }^{\mathrm{x}}$

\section{ORIGIN OF THE LOESS}

For a long time there had been dissatisfaction among geologists with the explanation of the great body of loess in the Mississippi Valley as of aqueous origin. Professor B. Shimek, of the University of Iowa, in particular, as a result of his extended studies opposed that idea on the grounds of fossil content, texture, and topographic distribution. He interpreted the loess as an eolian deposit formed, not in close connection with glaciation, but under interglacial conditions similar to those of the present day.

In the Journal of Geology, ${ }^{2}$ Professor Chamberlin presented a "Supplementary Hypothesis Respecting the Origin of the Loess of the Mississippi Valley." In this he cited some of the grave difficulties encountered by a theory of purely aqueous deposition of the main loess deposit. The observed relations, however, seemed to him "to force the conviction that the loess had its origin in some relationship to the Iowan stage and to the rivers that led away from the ice edge at that time." He adopted the glaciofluvial hypothesis "as the fundamental explanation of the origin of the Mississipian loess," and postulated low slope, extensive silt flats, and periodic floods for the "accumulation of fluvial loess, alternating with dry periods, when dust was being swept up by the winds from these flats and lodged in the vegetation on the adjoining lands where land mollusks were living." He held that "there must be an accommodation between the breadth and fluctuation of the fluvial deposits and the extent and massiveness of the eolian deposits."

\section{CHANGES IN PLEISTOCENE CLASSIFICATION}

After some question had been raised as to the applicability of Dawson's name "Albertan" to drift underlying the Aftonian inter-
x Journal of Geology, VIII (1900), 367-68.
${ }^{2}$ Vol. V (1897). 
glacial beds, the more or less indefinite names "pre-Kansan" and "sub-Aftonian" continued to be used and in their Geology $y^{\mathrm{x}}$ and their College Geology; ${ }^{2}$ Chamberlin and Salisbury used also the name "Jerseyan" taken from the oldest drift in New Jersey. It was stated in the 1906 volume $^{3}$ that "this older drift may not improbably be the equivalent of the sub-Aftonian of Iowa, but as direct connection cannot be traced the correlation is uncertain." In 1909, while studying the glacial and interglacial deposits of western Iowa and eastern Nebraska, Professor Shimek ${ }^{4}$ proposed the name "Nebraskan" for the pre-Kansan drift, and this convenient name has come into use by many geologists. Its selection, however, seemed to Dr. Chamberlin, for reasons stated in the Journal of Geology, ${ }^{5}$ to be "of doubtful wisdom" and he did not favor its use.

Some question having arisen as to the distinctiveness of the drift now called "Iowan" and as to its relative age, a co-operative arrangement was made under which the present writer, William C. Alden, for the United States Geological Survey, and M. M. Leighton, for the Iowa Geological Survey, spent most of the summer seasons of I9I4 and I9I 5 in a field study of the Iowan drift of northeastern Iowa and its relations, and their report was published in I9I 7 in the Iowa Geological Survey. ${ }^{6}$ On page 56 of that volume the authors stated that "the conclusion has been reached that there is what seems to the writers to be good evidence of the presence of a post-Kansan drift sheet in northeastern Iowa and that this drift appears to be older than the Wisconsin and younger than the Illinoian drift."

Many, if not most, of the geologists who have given any serious thought to the matter appear to be satisfied that there really is such a distinct drift sheet in northeastern Iowa, but there is still some difference of opinion as to its appropriate classification and nomenclature. It may not be out of place to give here the general classi-

I III (I906), 383 ff.

${ }^{2}$ Part II (I909), p. 840 . 3 P. 384 .

4 B. Shimek, "Aftonian Sands and Gravels in Western Iowa," Bulletin Geological Society of America, XX (I909), 408.

5 XVIII (I9I0), 294-95.

${ }^{6}$ XXVI, 49-2I 2. 
fication in use at present by the United States Geological Survey, ${ }^{\mathbf{I}}$ and in the building up of which T. C. Chamberlin had a much larger part than is indicated by the citations attached. This classification seems to the writer to serve the purposes of the present state of our knowledge fairly well. Some geologists, as did Dr. Chamberlin, prefer a somewhat different classification and undoubtedly with the increase of our knowledge modifications will be made. Even now local names are given various glacial and associated deposits when there is uncertainty as to their correlation with the deposits of the Mississippi Valley.

\section{STUDIES ON GLACIER MOTION IN GREENLAND}

In the summer of 1894 Dr. Chamberlin went to Greenland as geologist to the Peary Auxiliary Expedition and in the following December he took "Glacial Studies in Greenland" as the topic of his address as president of the Geological Society of America. Later a series of notable articles on the same subject were published in the Journal of Geology. ${ }^{2}$ Among the important points of his observations on the glaciers, discussed briefly in the presidential address, were the following:

Vertical ice fronts due to the sun's low angle of incidence. Stratification due to snowfalls. Dirt layers confined to the lower part of the ice. Introduction of débris by shearing radically different from the results of viscous flow and more like rigid thrust. The progressive growth of the ice granules a most important factor in glacier motion. As ice melts under pressure and refreezes on release of pressure, a granule may lose in one part and gain in another and thus move on its neighbors. The observations on crystallization of the ice oppose viscosity as an essential agency in the motion. A glacier does not push a moraine but

I With the omission of some of the later substages, the following is the classification in use at present by the United States Geological Survey:

PLEISTOCENE EPOCH

9. Wisconsin stage of glaciation (of Chamberlin).

8. Peorian stage of deglaciation (of Leverett).

7. Iowan stage of glaciation (of Iowa geologists).

6. Sangamon stage of deglaciation (of Leverett).

5. Illinoian stage of glaciation (of Leverett).

4. Yarmouth stage of deglaciation (of Leverett).

3. Kansan stage of glaciation (of Iowa geologists).

2. Aftonian stage of deglaciation (of Chamberlin).

I. Nebraskan stage of glaciation (of Iowa geologists)

(pre-Kansan of Chamberlin) (Jerseyan of Eastern United States).

${ }^{2}$ Vols. II-V, inclusive. 
rides over it. Observed daily rates of ice advance 0.4 to 2.78 feet. Average very slow. Not much recent advance or retreat. Greenland ice never advanced much if any beyond the present coast. Former elevation of Greenland was not coincident with conditions favoring glaciation.

Some of the results of his observations in Greenland were later incorporated in "A Contribution to the Theory of Glacial Motion." In a review of another paper, ${ }^{2}$ he stated the real proposition involved in the "granular theory," as follows:

I. Glaciers are formed of individual crystalline granules. II. These are controlled by a strong crystalline force. III. They are, however, subject to growth and decadence, resulting in the extinction of some crystals and the enlargement of others, and in changes of relations to one another. IV. The crystals of any part seem to be the enlarged or reduced descendants of those in the part above. V. Collectively they persist throughout the whole glacial movement, and individually they seem to persist through some notable part of it, at least. VI. They participate in the changes of form and the changes of attitude involved in the glacial movement.

The general nature of glacier motion has also been described as follows: ${ }^{3}$

The growth of ice granules, together with slight movement and adjustment between the granules under changing pressure conditions, is considered to be the underlying basic phenomenon. Compression produces heat and at the same time lowers the melting-point of ice. Compression becomes greatest at certain points of contact between granules. Liquefaction of minute portions of the granules will occur at the points of greatest compression; and, moving to points of less compression, this moisture becomes attached there by crystalline force. Actual melting, however, is not necessary. Slower transfer of molecule by molecule (idiomolecular transfer) accomplishes the result. As these transfers are in response to stress, the result is easing of the stress by yielding. Some granules lose and others gain, and their positions with respect to one another change somewhat. The summation of slight adjustments between innumerable granules is general movement of the mass in the lines of least resistance.

Associated with this granular motion there appears to be movement along shearing planes. Attempts to measure instrumentally this shearing were made on glaciers in the Canadian Rockies in r9ı, in Alaska in 1919, and in the Alps in 1921, by Dr. R. T. Chamberlin,

I Decennial Publications of the University of Chicago, series I, IX (I904), I9I-206.

${ }^{2}$ Journal of Geology, XV (1907), I89.

3 Rollin T. Chamberlin, "Instrumental Work on the Nature of Glacier Motion," Journal of Geology, XXXVI (I928), I9. 
using methods and apparatus which he and his father had devised. After some ineffectual trials, results were obtained which seemed to show that "at times there was almost no differential movement of the ice; at times there was a slow, steady shearing of the upper ice over the lower; while at other times there was a rapid slipping of the upper ice over the lower." It was inferred from the observations where the test was made that no great accumulation of differential stress could take place in glacier ice without causing adjustment. ${ }^{\mathbf{x}}$

\section{CAUSES OF CONTINENTAL GLACIATION}

Prior to the late I89o's one finds but little in T. C. Chamberlin's writings treating of the causes of continental glaciation. As the field mapping and study of the Pleistocene glacial deposits progressed in Europe and America and the evidence of diversity as opposed to unity of the glacial period accumulated, it became more and more evident that the current explanations as to the causes of continental glaciation did not meet the demands of the situation. Neither the postulated high elevations nor the planetary relations appealed to in Croll's and other astronomical hypotheses seemed competent to explain the very notable succession of alternating epochs of glaciation and deglaciation which were found to have taken place in Pleistocene time. These matters were being discussed at the University of Chicago and Chamberlin, with the co-operation of his colleagues and advanced students, began the work of building up a hypothesis in the hope of developing something more satisfactory. As the studies progressed the results were published in a series of articles in the Journal of Geology. A brief outline of the theory appeared in November, I897, under the title, "A Group of Hypotheses Bearing on Climatic Changes." This had been presented August 20, I897, before the Toronto meeting of the British Association for the Advancement of Science. Omitting the discussion of the conditions of enrichment of the atmosphere, certain excerpts may be taken from this article and from an article in Volume VI of the Journal of Geology entitled, "The Influence of Great Epochs of Limestone Formation upon the Constitution of the Atmosphere," as bearing on the depletion of the $\mathrm{CO}_{2}$ of the atmosphere and its effects on temperature:

r Op. cit., p. 2 I. 
Carbon dioxide, though quantitatively a minor component of the atmosphere, is necessarily a critical factor in vital processes and in many of the most important of inorganic processes. It is regarded, e.g., as "a leading agency in the disintegration of crystalline rock."

Chamberlin states: $:^{x}$

... . If a computation be made of the amount of carbon dioxide that would be required to disintegrate the crystalline rock requisite to supply the clastic material for a great epoch of sandstone and shale deposition (allowing duly for old clastics used over), a competency to exhaust many atmospheric equivalents of carbonic acid will be shown. This, being correlated with limited limestone formation, and consequent scant returns of carbonic acid from the ocean, seems competent on its side to notably change the constitution of the atmosphere in the direction of poverty of carbonic acid. .... .

Let us assume for the moment a uniform supply equal to the average rate of exhaustion. With the inauguration of any great epoch of general uplift there would begin an era of relatively rapid atmosphere exhaustion, which would proceed continuously during such elevated stage and might result in notable atmospheric impoverishment, as the computations cited early in this paper show. As the cutting down of the surface approached baselevel, the depletion would be retarded and, the supply continuing the same by hypothesis, the rate of exhaustion would fall below that of supply and an epoch of enrichment begin. A second elevation would re-inaugurate the depletion, and so oscillations of enrichment and impoverishment would follow the general oscillations of the land surface. Applying this law by itself, atmospheric poverty should follow at some distance the stages of general elevation, and, on the other hand, atmospheric enrichment should follow at some distance the stages of baseleveling or depression. . . . .

It is impossible here to attempt to apply the doctrine in detail to geological history. But it may be noted in passing that the Pleistocene glaciation followed at a notable interval the formation of the great plateaus and epeirogenic uplifts of late Tertiary times. The glaciation of India, Australia, and South Africa occurred about the time of the crustal revolutions that marked the close of the Paleozoic era. The uncertainty of the homotaxis of the strata involved makes a precise correlation at present impossible. The glaciation perhaps came too early to fit the hypothesis. Here, at least, is an excellent chance to put it to trial. All other hypotheses of glaciation have fared badly when brought to the supremely severe test of the ancient oriental low-latitude glaciation, and if this hypothesis shall follow them to the junk shop of broken down theories it will find an already beaten path. ....

It is now a little more than fifty years since Tyndall suggested that the periods of terrestrial glaciation might be dependent upon the carbon dioxide of the atmosphere whose peculiar competence to retain solar heat he had demonstrated. The suggestion of the origin of glaciation through the depletion of this

I Journal of Geology, VI, 620; V, 678 and 680-82. 
atmospheric constituent is, therefore, not at all new. It has been entertained by others than Tyndall. If it has failed to find much acceptance this has perhaps been partly from a doubt as to its adequacy and partly from the lack of any definitely assignable cause for the requisite intermittent depletion. Dr. Arrhenius has recently contributed to the subject a most important discussion bearing especially upon the former point. ${ }^{x}$ By an elaborate mathematical analysis of data derived from Langley's experiments he has endeavored to ascertain what degree of depletion of the carbon dioxide of the present atmosphere would bring on the conditions of Pleistocene glaciation, and, on the other hand, what degree of enrichment would produce the warm climate of the Tertiary. He arrives at the conclusion that the removal of 38 to 45 per cent of the present carbon dioxide would bring on glaciation and that an increase of 2.5 or 3 times its value would produce the mild temperatures of the Tertiary times. He quotes the opinion of Professor Högbom in support of the competency of earth changes to produce this depletion, and also the competency of the interior and other sources to resupply the impoverished atmosphere. He, therefore, carries the suggestion of Tyndall and others a very notable step in advance, and, what is especially important, has given it quantitative expression on the basis of deductions from observed data. He does not, however, postulate the conditions which control the enrichment and depletion of the atmosphere which has been the essential endeavor of this paper. ${ }^{2}$

But we do not meet geological demands when we simply offer general explanations of climatic changes. Our theories must ultimately be found to fit the precise phenomena. How are we to explain the profound glacial oscillations? . . . I I have endeavored to follow out the doctrine of atmospheric gain and loss on its own lines, and although the studies are incomplete, the results are at least encouraging. I seem to find a rhythmical action that may in part explain the glacial oscillations. To do it justice it should have elaborate and careful statement, but I can here only suggest its nature in bald outline and in terms that need qualification. The idea hinges (I) on the action of the ocean as a reservoir of carbon dioxide and (2) on the losses of the organic cycle under the influence of cold. Cold water absorbs more carbon dioxide than warm water. As the atmosphere becomes impoverished and the temperature declines, the capacity of the ocean to take up carbon dioxide in solution increases. Instead, therefore, of resupplying the atmosphere in the stress of its impoverishment, the ocean withholds its carbon dioxide to a certain extent, and possibly even turns robber itself by greater absorption, though the diminution of the tension of the carbon dioxide of the atmosphere as its amount is reduced tends to in-

I Svente Arrhenius, Phil. Mag., S. 5, XLI, No. 25I (April, I896), 237-79.

${ }^{2} \mathrm{I}$ may here remark that the main features of the ideas herein advanced were entertained and expressed to my students some time before I saw Dr. Arrhenius' important paper, but I fear I might not have felt justified in giving them a more public statement but for the encouragement of weighty opinion on the vital point of quantitative sufficiency.-T. C. C. 
crease the discharge of carbon dioxide from the ocean to restore the equilibrium, and, to the degree of its efficiency which is undetermined, offsets the increased absorption of the cold water. So also, with increased cold the process of organic decay becomes less active, a greater part of the vegetal and animal matter remains undecomposed, and its carbon is thereby locked up, and hence the loss of carbon dioxide through the organic cycle is increased. The impoverishment of the atmosphere is thus hastened and the epoch of cold is precipitated.

With the spread of glaciation the main crystalline areas, whose alteration is the chief source of depletion, become covered and frozen, and the abstraction of carbon dioxide by rock alteration is checked. The supply continuing the same, by hypothesis, reenrichment begins, and when it has sufficiently advanced warmth returns. With returning warmth, the ocean gives up its carbon dioxide more freely, the accumulated organic products decay and add their contribution of carbonic acid, and the reenrichment is accelerated and interglacial mildness hastened.

With the reexposure of the crystalline areas, alteration of the rocks is renewed and depletion reestablished and a new cycle inaugurated. And so the process is presumed to continue until a change in the general topographic conditions determines a cessation.

The localization of North American and European glaciation is regarded as due to the great areas of permanent atmospheric depression near Greenland, the Aleutian Islands, and the related storm tracts.

As to periodicity, it is stated ${ }^{\mathrm{x}}$ in part:

The basal conception is that, under general conditions favorable for glaciation, certain of the agencies involved became dominant and tended to intensify and accelerate glaciation for a time, until they either pushed the effects to an extreme from which a reaction was inevitable, or they exhausted themselves temporarily, while other agencies of opposite phase, which had been subordinate until then, became dominant and forced a reaction.

When a reaction was set up, it in like manner was pushed to an extreme, and deglaciation extended beyond the point of equilibrium for the average conditions. And so oscillations beyond and short of the mean state, gave a rhythmical phase to the glaciation of the period. The rhythm, we learn from observation, took the form of a series of sub-equal oscillations with declining time-intervals. There seem to have been no great differences in the amplitude of the ice advances. Observation does not permit us to speak as confidently of the extents of the recessions. It is important to note that the fundamental or general conditions remained effective throughout the period, and that the oscillations are regarded only as rhythms superposed on these general conditions. The more intense phases of these rhythms were, however, the only portions of the series that recorded themselves in glaciation near the borders of the glaciated

${ }^{x}$ Chamberlin and Salisbury, Geology, III (Ig06), 433 and 436. 
areas, and were perhaps the only portions that recorded themselves in continental glaciations at all. The retrocessional phases may have been recorded only in cool climates in high latitudes, and in glaciation at high altitudes.

LATER CONNECTIONS WITH FEDERAL AND STATE SURVEYS

In the late I89o's and in the I900's, Professor Chamberlin turned more and more to the broader fields of geology and cosmogony, with which this sketch has not to deal, and as time went on he wrote fewer papers on glacial geology. He continued his supervision of the glacial investigations for the Federal Survey, however, for many years and was frequently in consultation with members of state surveys. Among those of whose glacial studies he had supervision for periods of different lengths were: R. D. Salisbury, F. B. Taylor, W. G. Tight, James H. Smith, J. W. Goldthwait, and T. O. Mabry. He had also close connection with studies made in the West for the Federal Survey, under the immediate direction of R. D. Salisbury, by W. W. Atwood, G. H. Garrey, Eliot Blackwelder, F. H. H. Calhoun, S. R. Capps, and others. The present writer counts it a great privilege to have worked for many years in southeastern Wisconsin, and for shorter periods in Illinois, Pennsylvania, and Massachusetts, under the immediate supervision of Dr. Chamberlin. Mr. Leverett's association with him began about ten years earlier and continued for a longer time. These various studies were in widely scattered fields in many different states and from these has come a long series of official and other papers bearing the direct impress of Dr. Chamberlin's masterly mind. Of these perhaps the most notable are the monographs by Mr. Leverett; besides those cited above, Leverett's official reports include the following: Monograph 4I, "Glacial Formations and Drainage Features of the Erie and Ohio Basins; Monograph 53, "The Pleistocene of Indiana and Michigan and the History of the Great Lakes"' (with F. B. Taylor); Professional Paper I54, "Moraines of the Lake Superior Basin" (in press); Professional Paper —-, "Quaternary Geology of Minnesota" (in preparation).

Even after Professor Chamberlin had retired from active connection with the Federal Survey and with the University of Chicago, glacial geologists of this and other countries sought his counsel. His direct influence in glacial geology was long continued and by no 
means circumscribed by the limits of his fatherland. Some of the latest of his unpublished writing was in regard to the classification of the Pleistocene of the Mississippi Valley.

In closing this sketch concerning the contributions of Thomas Chrowder Chamberlin to glacial geology, the writer cannot do better than to call to mind that "restraint, patience, and equipoise" which quite generally characterized his treatment of students and colleagues even under the occasional stress of great provocation. In the old days at the University of Chicago, and ever afterward, his students spoke affectionately of him as a kindly gentleman, a great scholar, and an inspiring teacher. 